\title{
Nitric oxide and pulmonary hypertension
}

\author{
Ji-Yeon Sim \\ Department of Anesthesiology and Pain Medicine, Asan Medical Center, College of Medicine, University of Ulsan, Seoul, Korea
}

\begin{abstract}
Pulmonary hypertension is a serious complication of a number of lung and heart diseases that is characterized by peripheral vascular structural remodeling and loss of vascular tone. Nitric oxide can modulate vascular injury and interrupt elevation of pulmonary vascular resistance selectively; however, it can also produce cytotoxic oxygen radicals and exert cytotoxic and antiplatelet effects. The balance between the protective and adverse effects of nitric oxide is determined by the relative amount of nitric oxide and reactive radicals. Nitric oxide has been shown to be clinically effective in the treatment of congenital heart disease, mitrial valvular disease combined with pulmonary hypertension and in orthotropic cardiac transplantation patients. Additionally, new therapeutic modalities for the treatment of pulmonary hypertension, phosphodiesterase inhibitors, natriuretic peptides and aqueous nitric oxide are also effective for treatment of elevated pulmonary vascular resistance. (Korean J Anesthesiol 2010; 58: 4 14)
\end{abstract}

\section{Key Words: Nitric oxide, Pulmonary hypertension, Pulmonary vascular resistance.}

Pulmonary hypertension (hereinafter PHT), which has numerous causes, results from increased pulmonary resistance and constriction of pulmonary vessels. Clinical treatment of pulmonary hypertension is difficult, and the disease entity can indirectly trigger right ventricular failure, which can lead to death. Studies conducted in the 1980s revealed that nitric oxide (NO) is related to the etiology of PHT, and various drugs for PHT treatment with minimal NO side-effects have recently been developed. Here, we discuss clinically erroneous prognoses of the pathophysiology of PHT, the mechanism of NO treatment, its actual use in practice, its toxicity, and other drug therapies used for the treatment of PHT.

\section{Pathophysiology of pulmonary hypertension}

PHT is the occurrence of pulmonary resistance accompanied by elevated pulmonary arterial pressure. There are primary and secondary causes of PHT. Secondary PHT is characterized by prolonged vasoconstriction caused by different acute, chronic pulmonary or cardiac disorders. This condition creates a structural abnormality in the blood vessel base that is

Received: December 19, 2008. Accepted: January 15, 2009.

Corresponding author: Ji-Yeon Sim, M.D., Ph.D., Department of Anesthesiology and Pain Medicine, College of Medicine, Asan Medical Center, University of Ulsan, 338-1, Pungnap-dong, Songpa-gu, Seoul 138-736, Korea. Tel: 82-2-3010-3868, Fax: 82-2-470-1363, E-mail: jysim@ amc.seoul.kr

(c) This is an open-access article distributed under the terms of the Creative Commons Attribution Non-Commercial License (http:// creativecommons.org/licenses/by-nc/3.0/), which permits unrestricted non-commercial use, distribution, and reproduction in any medium, provided the original work is properly cited. 
accompanied by hypoxia and an inflammatory response, which eventually leads to elevated pulmonary resistance. It is important to note that secondary PHT also causes the original disorder to worsen (Table 1) [1,2]. Primary PHT is defined as a pulmonary arterial pressure greater than $25 \mathrm{~mm} \mathrm{Hg}$ at rest or greater than $30 \mathrm{~mm} \mathrm{Hg}$ during exercise. If not treated, the life span of an individual with PHT is about 2.8 years and the 5 -year survival rate is only around $34 \%$. The ultimate cause of death as a result of primary PHT is right ventricular dysplasia and right ventricular failure. Although quite rare, primary PHT

Table 1. Diagnostic Classification of Pulmonary Hypertension

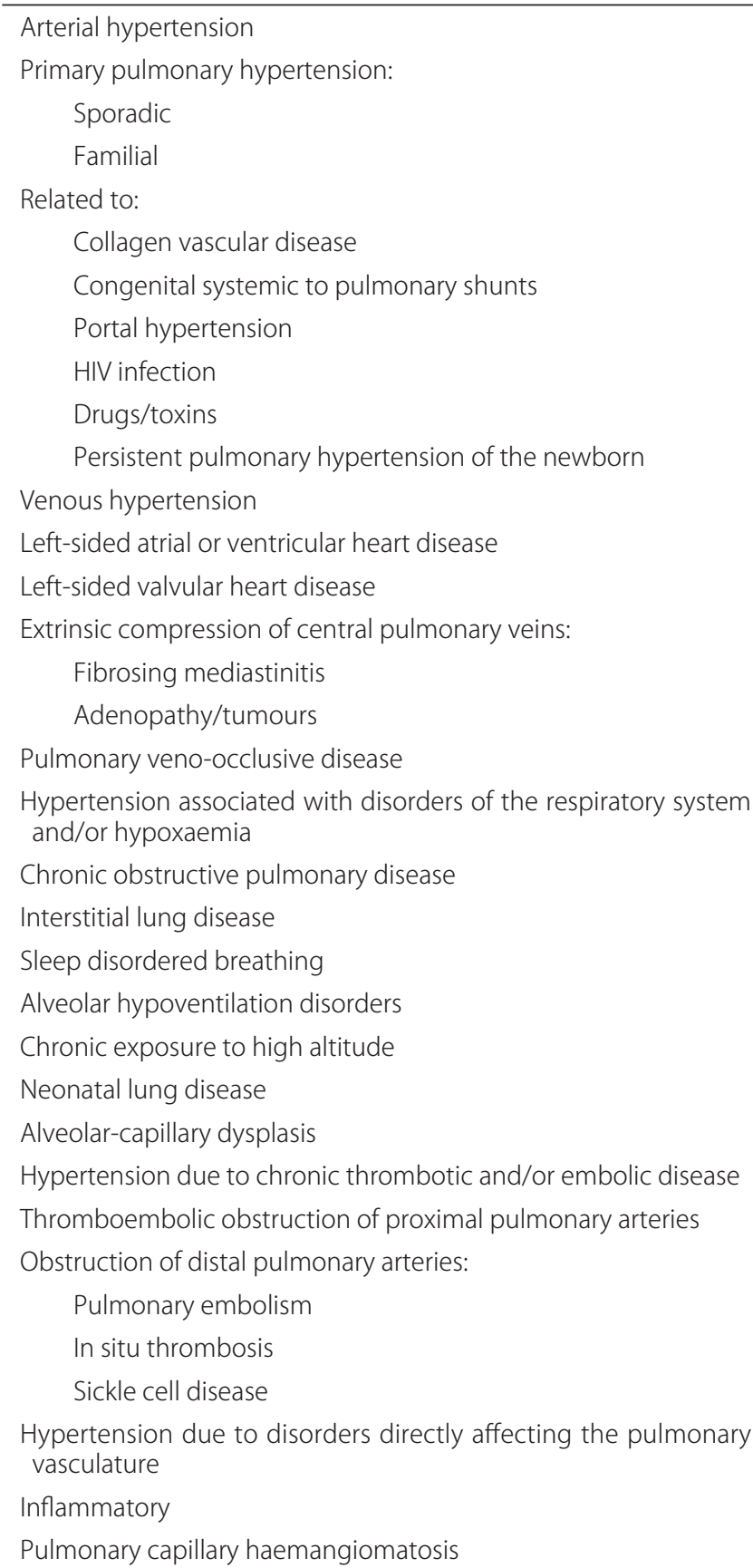

Sporadic

Collagen vascular disease

Congenital systemic to pulmonary shunts

Portal hypertension

HIV infection

Drugs/toxins

Persistent pulmonary hypertension of the newborn

Left-sided valvular heart disease

Fibrosing mediastinitis

Adenopathy/tumours

Pulmonary veno-occlusive disease

and/or hypoxaemia

Chronic obstructive pulmonary disease

Alveolar hypoventilation disorders

Chronic exposure to high altitude

Neonatal lung disease

Alveolar-capillary dysplasis

Hypertension due to chronic thrombotic and/or embolic disease

Thromboembolic obstruction of proximal pulmonary arteries

ostruction of distal pulmonary arteries:

$$
\begin{aligned}
& \text { Pulmonary embolism } \\
& \text { In situ thrombosis }
\end{aligned}
$$

vasculature

Pulmonary capillary haemangiomatosis is most commonly found in Caucasians, younger individuals and women. In addition, primary PHT is occasionally dominantly-inherited $[3,4]$.

Elevated pulmonary resistance during PHT occurs due to increased vascular tone and structural remodeling of the peripheral pulmonary arteries. During remodeling, vascular smooth muscles undergo hypertrophy and proliferate, which results in the quantity of vascular connective tissue increasing. As the endothelial cells are impacted, the blood vessel diameters eventually constrict and pulmonary resistance increases. Normal pulmonary circulation is characterized by a high blood flow rate, low resistance and low pressure. Pulmonary resistance is controlled by vascular smooth muscle cells and oxygen tension inside the alveoli, $\mathrm{K}^{+}$channel activity and many vasoactive mediators. However, when pulmonary blood flow increases abnormally, pulmonary blood vessels are continuously strained from the pressure and the blood vessel walls are damaged. As a result, mesons such as angiotensin II, endothelin-1, 5-hydroxytryptamine and inflammatory cytokine are produced. In cells, $\mathrm{Ca}^{++}$and protein kinase- $\mathrm{C}$ act as mediators, thicken blood vessel walls and induce the inside walls to grow, thereby causing remodeling [5-8]. Pulmonary resistance also increases in response to decreases in the number of pulmonary vessels per segment. Such changes begin with peripheral arteriole vascular smooth muscle before the capillaries.

As the formation of abnormal blood vessels progresses, control of the vascular tone decreases and the blood vessels constrict. This causes hypoxia, which then causes hypoxic pulmonary vasoconstriction. As this process repeats, it eventually leads to abnormalities in the endothelium. In other words, structural abnormalities cause functional abnormalities (Fig. 1) [9]. The cause of acute and chronic hypoxia in PHT differs

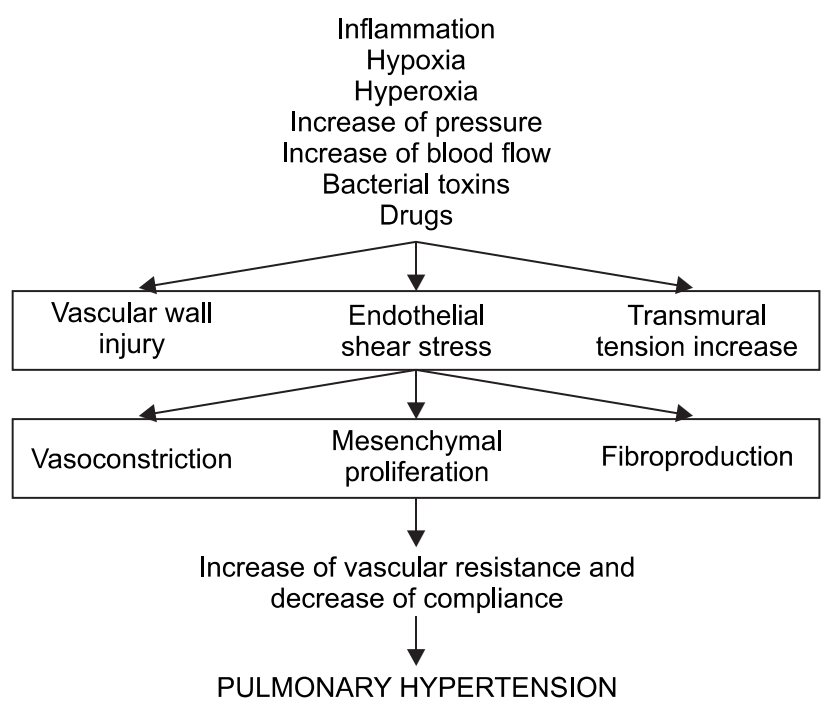

Fig. 1. Major mechanisms causing pulmonary hypertension. 
slightly. Specifically, hypoxic pulmonary contraction is the cause of acute hypoxia, whereas elevated pulmonary resistance due to structural remodeling is the main cause of chronic hypoxia [10].

\section{Nitric oxide in pulmonary hypertension}

NO has a low molecular weight, is oleophilic and is a very fast-reacting endogenous free radical. In vascular endothelial cells, NO is produced by NO synthases (NOS). The precursor to $\mathrm{NO}$ is the terminal guanidine nitrogen of L-arginine, and its formation also requires nicotinamide-adenine dinucleotide phosphate and oxygen. The vasodilatory mechanism of NO can be briefly explained as follows: $\mathrm{NO}$ in high concentration is quickly oxidized into toxic nitrite $\left(\mathrm{NO}_{2}{ }^{-}\right)$or nitrate $\left(\mathrm{NO}_{3}{ }^{-}\right)$; however, at low concentrations, $\mathrm{NO}$ diffuses into the smooth muscle. Once inside the muscle cells, NO is iron and sulfurfriendly, which enables it to easily combine with and activate the heme of guanylate cyclase, which raises the concentration level of intracellular cGMP. Intracellular cGMP induces vasodilation via many mechanisms. For example, it activates cGMPdependent protein kinase, which inhibits $\mathrm{Ca}^{++}$entry into the

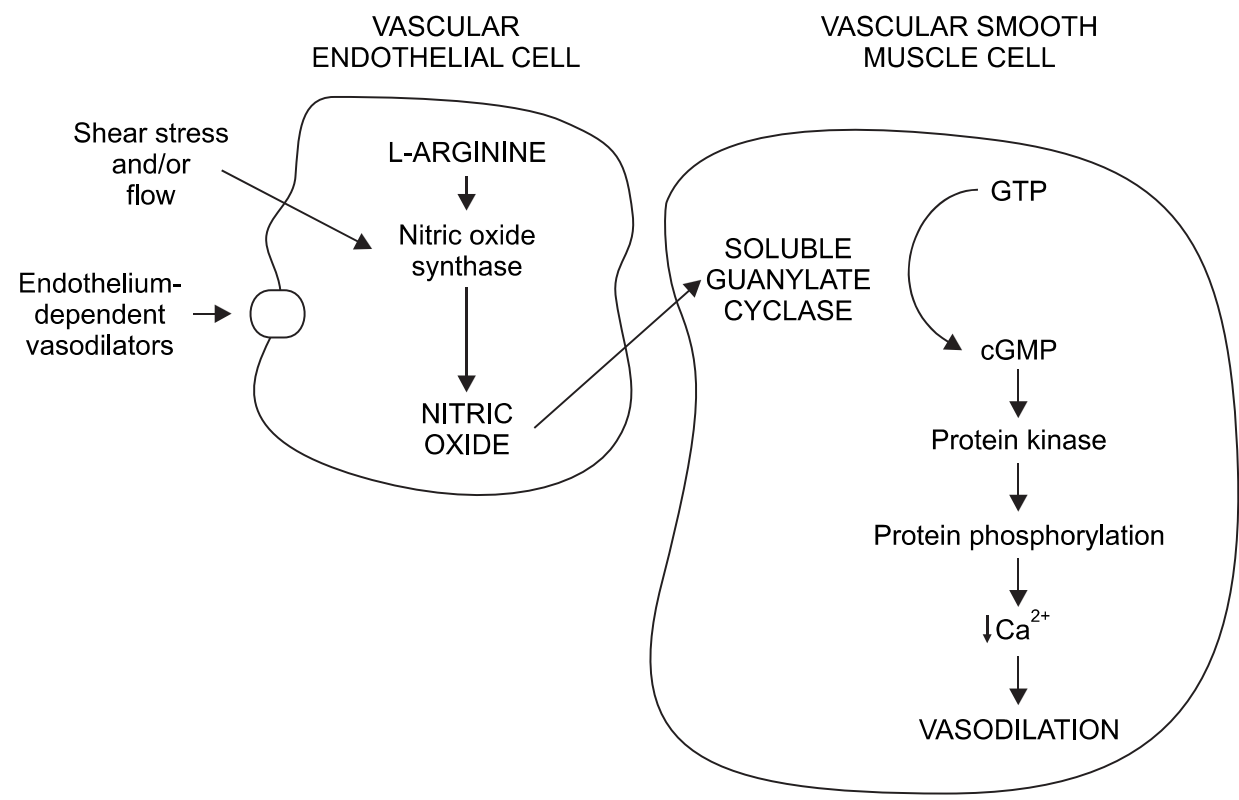

Fig. 2. Schematic diagram showing the proposed mechanism for activation of soluble guanylate cyclase by nitric oxide.

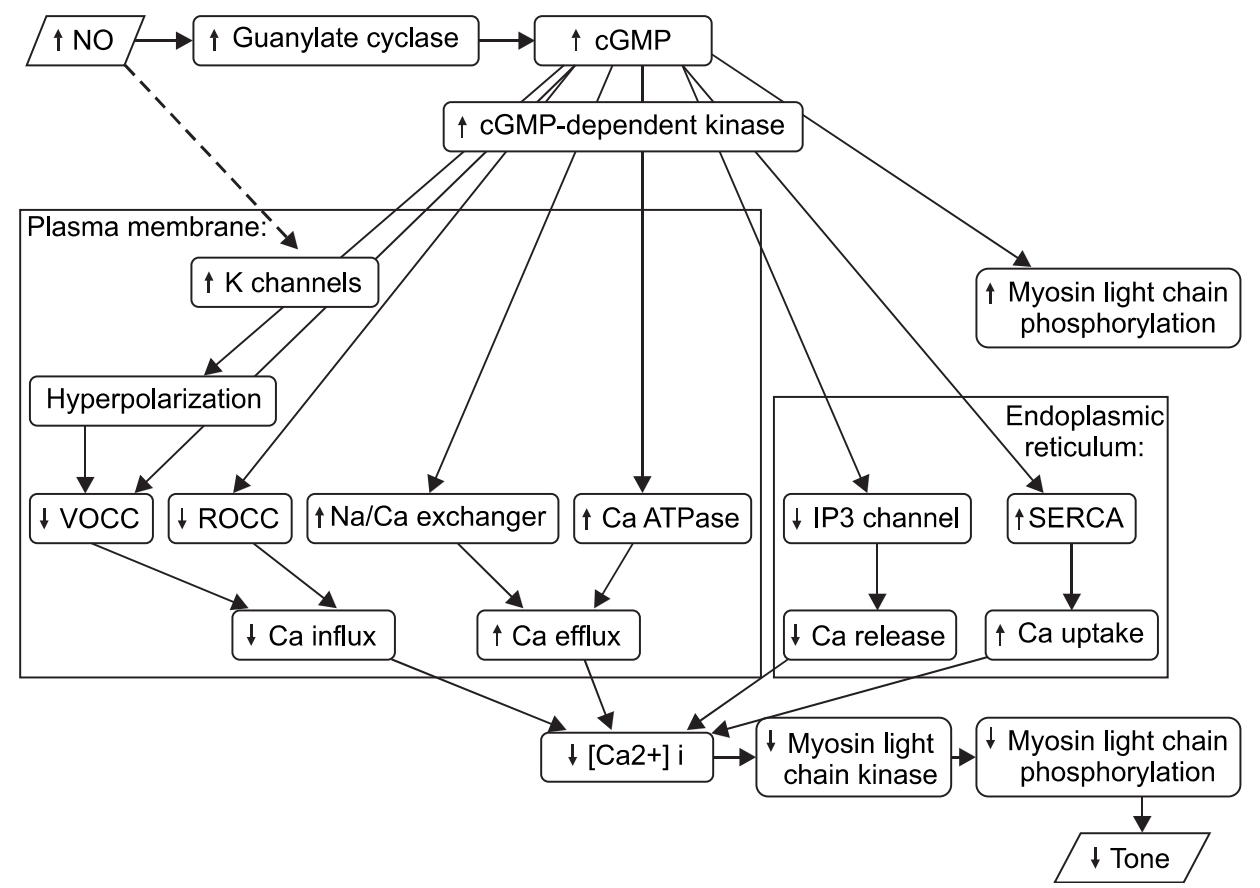

Fig. 3. Mechanisms of nitric oxide/ cGMP-induced vasodilation. VOCC: voltage-operated calcium channels, ROCC: receptor-operated calcium channels, SERCA: sarcoplasmic/endoplasmic reticulum $\mathrm{Ca} 2+$ ATPase, IP3 channel: inositol 1,4,5-trisphosphate-gated calcium channel, [Ca2+]i: intracellular free calcium ion concentration. 
cell, causes $\mathrm{Ca}^{++}$to leave the cell, sequestrates $\mathrm{Ca}^{++}$in the sarcoplasmic reticulum (SR) and reduces intracellular $\mathrm{Ca}^{++}$. In addition, intracellular cGMP activates myosin light chain phosphatase, reduces phosphorylation in the myosin thereby sustaining the vascular smooth muscle tone, and reduces vascular tone [11-14] (Fig. 2, 3). NO combines with oxy-Hb in the blood and to produce met-Hb which is reduced by a reductase and also combines with oxygen and forms $\mathrm{NO}_{3}{ }^{-}$ and $\mathrm{NO}_{2}{ }^{-}$which are excreted in urine [15].

$\mathrm{NO}$ works as a biological controller in many organs. One of its most important functions is regulation of the vascular smooth muscle (Table 2). In 1980, Furchgott and Zawadzki first reported that endothelial cell integrity is vital during achetylcholine vasodilation. They were also the first to report the existence of EDRF (endothelial-derived relaxing factor) [16]. In 1987, Palmer et al. demonstrated that the substance produced in normal vascular endothelial cells was in fact NO [17]. Later, they found that chronic inflammatory respiratory patients lacking pulmonary vasodilatory function had reduced endothelial NOS and NO activity [18].

Studies conducted to determine if the administration of NO suppresses vascular smooth muscle constriction and fibroblast proliferation [19] strongly suggest that $\mathrm{NO}$ affects vasodilation. NOS is found in three isoforms: neuronal NOS (nNOS), inducible NOS (iNOS) and endothelial NOS (eNOS). eNOS is primarily known for its role in vasodilation $[20,21]$. To determine what role NO plays in controlling vascular tone in normal blood vessels, different quantities of the NOS inhibitors, N-monomethyl-L-arginine (L-NMMA), N-nitro-Larginine methyl ester (L-NAME) or N-nitro-L-arginine (L-NA) were added to different animal lung models using different administration methods. The results showed that when NOS inhibitors were administered, NO production was inhibited and endothelium-derived vasodilation was reduced in healthy

Table 2. Roles of Intrinsic Nitric Oxide in Various Organ Systems

\begin{tabular}{ll}
\hline \multicolumn{1}{c}{ Organ system } & \multicolumn{1}{c}{ Roles of intrinsic NO } \\
\hline Vascular smooth muscle & Regulator of vascular tone \\
Nervous system & Neurotransmitter \\
& Neuronal pruning \\
Gastrointestinal tract & Gut motility \\
& Villar flow \\
& Fluid/electrolyte transport \\
Inflammatory and immune & Lymphocyte mediator \\
system & Tumorstatic and tumorcidal \\
& activities \\
& Antimicrobial action \\
Reproductive system & Erectile tissue function \\
Miscellaneous & Platelet aggregation inhibitor \\
& Bronchodilation \\
& Antiproliferative properties \\
\hline
\end{tabular}

blood vessels. Additionally, increased quantities were found to trigger pulmonary vasoconstriction. Furthermore, the effects of L-NAME and L-NA were greater than those of L-NMMA [2225]. The role of $\mathrm{NO}$ in vasoconstriction has also been evaluated through a wide variety of animal test models. More NO production was observed in models in which pulmonary resistance increased due to hypoxia and the administration of angiotensin II than in the normal pulmonary resistance model. In addition, hypoxic pulmonary vasoconstriction was more intense in response to L-NAME and L-NA than normal PVR $[23,26,27]$. Increased NO reduces pulmonary resistance, but also produces toxic radicals, although less amount produced than in adult respiratory distress syndrome, and NO can lead to blood vessel damageThe balance of cell toxicity and cell integrity is determined by each radical fraction, which determines the final reaction [28-30].

After the discovery of the pathway through which NO affects vascular relaxation and vascular tone, many studies were conducted to identify ways in which NO could be used clinically. Frostel et al. and Pepke-Zaba et al. reported that administration of $\mathrm{NO}$ at 40 ppm to adult patients with primary high pulmonary blood pressure could selectively reduce pulmonary resistance without altering the systemic vascular resistance $[31,32]$. Since then, many clinical studies of various patient groups have shown the utility of NO in the diagnostics, treatment and prognoses of PHT in patients such as newborn babies, as well as those with juvenile hereditary heart disease accompanying PHT, adult respiratory distress syndrome and chronic obstructive pulmonary diseases [3,15,33-39].

\section{Nitric oxide in cardiac surgery}

Pulmonary hypertension can occur even after cardiopulmonary bypass because of microembroli, ischemia, sedimentation of blood cells or stress reaction. Existing methods of reducing pulmonary resistance before and after surgery include systemic alkalization, $\mathrm{O}_{2}$ therapy, increased cardiac contractility, stress reaction reduction, anticoagulant drugs and vascular relaxants. The most commonly used drugs are alpha-adrenal receptor antagonists, beta-lactam antibiotics, nitrates, $\mathrm{Ca}^{++}$channel blockers and prostaglandins. However, these drugs seriously reduce systemic vascular resistance and cause unstable vital signs $[40,41]$. When PHT cannot be corrected with drugs, extracorporeal circulation is conducted to induce oxygenation; however, there are no special methods of treatment besides symptomatic therapy, and often needed long-term hospitalization.

Following cardiopulmonary bypass, elevated pulmonary resistance does not subside in response to achetylcholine administration, but it does subside in response to NO inhalation. In addition, the administration of NO has been found to 
increase the cGMP level. Although the vasodilatory effect is not endotheliocyte-dependent, NO has been shown to have a direct relaxant effect [5]. There have also been many reports of $\mathrm{NO}$ administration selectively reducing pulmonary resistance during mitral valve replacement due to stenosis, mitral valve replacement accompanied by right ventricular failure and LVAD insertion due to left ventricular failure, heart transplantation and before and after various cardiac surgeries [42-47].

It has also been argued that when compared to prostacyclin, $\mathrm{NO}$ is more effective at reducing PHT [44]. However, although the two drugs induce a similar reduction in pulmonary resistance, prostacyclin has a low toxicity and is easier to administer; therefore, it is more commonly recommended $[43,46]$. When compared to milrinone, NO keeps the heart rate low and better sustains the right ventricular index and systemic arterial pressure [47]. In addition, there was a case report of an allograft liver transplant in which the patient experienced serious PHT mid-operation that was effectively reduced by combined treatment with prostacyclin and NO [48]. In a comparative study of the recently developed inhalant $\mathrm{PGI}_{2}$ drug, iloprost, both $\mathrm{NO}$ and $\mathrm{PGI}_{2}$ successfully reduced $\mathrm{PHT}$ after a cardiac pulmonary bypass, but it was not determined which drug was most effective. Furthermore, both drugs have similar effects and it has been reported that when used together they have a synergistic effect [49]. Prostaglandin has the same effects as NO, but its mechanism in capillary

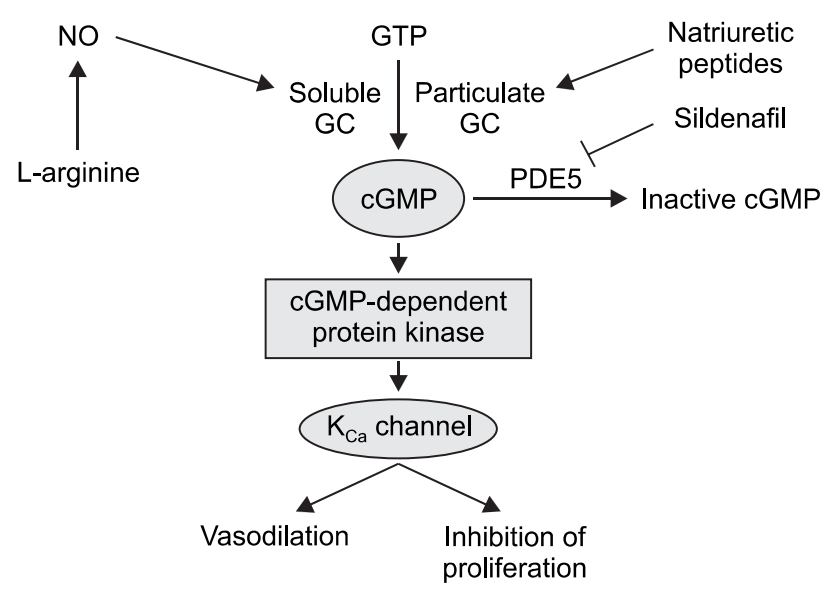

Current opinion in pharmacology

Fig. 4. Schematic representation of the cGMP pathway that mediates vasodilation and inhibition of cellular proliferation of drugs. relaxation is different. Specifically, NO activates cGMP and relaxes the vascular smooth muscles, while iloprost raises the intracellular cAMP level, activates $\mathrm{Ca}^{++}$, opens the $\mathrm{K}^{+}$channel and reduces pulmonary resistance (Fig. 4). Another advantage of iloprost is that its half-life is longer than that of NO, which results in a low occurrence of rebound PHT during weaning [50].

The use of NO during a perioperative period, especially postsurgery, has produced a variety of responses. Furthermore, the differences in responses have not necessarily been proportional to the dosage amount, but are known to be influenced by many factors related to surgery such as hemodynamic management and ventilation conditions. Accordingly, it is difficult to predict the standard effects of NO, which necessitates that drug therapy be selected on a case by case basis to magnify the desired effect and minimize the side effects. Moreover, in the event of intraoperative uncorrectable emergency PHT, NO should be used first, while the use of ECMO should be considered only if NO is not effective $[15,39]$.

\section{Therapeutic use of NO}

Since it was approved for medical use by the FDA in 1999, NO has been very useful in clinical research. In patients undergoing mechanical ventilation, NO is connected to an artificial ventilation system with deseired flow-rate after regulation of pressure (Table 3 ). During its administration, NO inhalation and the $\mathrm{NO}_{2}$ levels are monitored just proximal the tracheal tube using an electrochemical analysis machine, as is the expiratory gas flow. Patients without tracheal tubes simply supply NO through an oxygen mask or hood, but expired gas and redundant gas must be carefully removed using a vacuum [51].

Although treatment with $\mathrm{NO}$ at levels below 0.8 ppm has been reported to have pulmonary vasodilatory effects [52], treatment with 2-80 ppm is usually most effective $[53,54]$. As a result, treatment generally starts at 5-20 ppm, and the dosage is then increased to a maximum of $80 \mathrm{ppm}$ if there is no reaction within a few minutes. However, it is recommended that less than 40 ppm be administered during chronic NO treatment $[7,51]$. Overall, it is important to administer the lowest effective dose while continuously monitoring the $\mathrm{NO}_{2}$ level and maintaining the inhaled oxygen level between 0.4 and 0.6 to minimize oxygen and $\mathrm{NO}_{2}$ toxicity [55].

Table 3. New Therapies in Primary Pulmonary Hypertension

\begin{tabular}{lll}
\hline \multicolumn{1}{c}{ Therapy } & Dosage/Route of administration & \multicolumn{1}{c}{ Patient population } \\
\hline Inhaled NO & $5-40 \mathrm{ppm}$ by inhalation & Infants with hypoxic respiratory failure and pulmonary hypertension \\
O-Nitrosoethanol & $0.0025-0.125 \%$ by inhalation & Persistent pulmonary hypertension of the newborn \\
Sildenafil & $50 \mathrm{mg} \mathrm{po} \mathrm{q8h}$ & Primary pulmonary hypertension (with or without inhaled NO or inhaled iloprost) \\
Bosentan & $125-150 \mathrm{mg}$ po bid & Primary pulmonary hypertension \\
\hline
\end{tabular}


During NO treatment, it is recommended that the central venous pressure, pulmonary arterial pressure, systemic arterial pressure and systemic oxygen saturation be measured. However, if this is not practical, it is essential to monitor the systemic arterial pressure and oxygen saturation. Furthermore, post-operative patients or ICU patients need to be provided with sedatives as well as additional hyperventilation.

At 24 hours after the start of treatment, the NO can be reduced and weaning may be considered depending on the patient's condition. At this point, the NO concentration can be slowly reduced from 10 ppm to $0-5$ ppm. During this initial weaning period, the pulmonary arterial pressure and systemic arterial pressure should be carefully monitored. An increase in pulmonary arterial pressure and a decrease in systemic arterial pressure within the first 1-2 min signifies a failure in weaning, indicating that $\mathrm{NO}$ administration must not be stopped. Additionally, if the patient condition is unstable during weaning, re-administration of $\mathrm{NO}$ at the previous level should be considered. After re-administration, weaning may be considered after 24 hours. NO weaning should be conducted progressively so that the endotheliocytes can recover from the endogenous $\mathrm{NO}$ inhibition and downregulation from the exterior NO administration [56]. Indeed, sudden weaning can poses the risk of causing serious hypoxia and rebound PHT. When weaning from $\mathrm{NO}$ administration, temporary pulmonary arterial pressure or vascular resistance may rebound and increase, but this is different from weaningfailure. Rather, this happens several minutes after stopping $\mathrm{NO}$ administration. Although the pulmonary arterial pressure increases, the systemic arterial pressure and the oxygen saturation often remain the same, and the pulmonary arterial pressure then decreases after several minutes. It is believed that this phenomenon occurs due to a decrease in the production of endogenous NO.

The length of the administration period cannot be set uniformly, but must be set differently for each patient. For an adult, NO is generally administered for several days to several weeks, but the average administration period is five days [57]. When the pulmonary resistance is greater than six wood units, NO should be administered for more than 72 hours while taking care when decreasing the right ventricle afterload [51]. Patients with post-surgery PHT that is unresponsive to NO treatment do not have a good prognosis. Additionally, juvenile patients with post-surgery PHT often experience cyanosis. If such patients are unresponsive to $\mathrm{NO}$, it is important to check for pulmonary venous occlusion and any pulmonary arterial malformations [58]. Through the preoperative administration of $\mathrm{NO}$ in patients preparing for a heart transplant, we can check the responsiveness of the pulmonary vasculature to determine if surgery is possible and to evaluate the prognosis [59].

Recently, there has been increased research into treatment with liquid NO dissolved into normal saline and injected into the brachial artery. The results of these studies have shown that the administration of $0.75-6 \mu \mathrm{mol} N \mathrm{NO}$ causes rapid radial artery relaxation and stabilizes the decrease in resistance for 20 seconds. Additionally, these studies have shown that large quantities of plasma $\mathrm{NO}_{2}$ and $\mathrm{NO}_{3}$ were produced in response to this treatment, as well as s-nitrosothiol (RSNOs), which is assumed to be the substance that prolongs pulmonary vasodilation [60].

\section{Toxicity of nitric oxide}

Before NO was known for its utility, it was known as an environmental toxin with great cytotoxicity. For example, cigarette fumes are known to contain an average of 400 ppm of $\mathrm{NO}$ and polluted air often contains up to $0.2 \mathrm{ppm}$ of $\mathrm{NO}_{2}$. Endogenous $\mathrm{NO}$ is also believed to be the cause of oxidationmediated tissue damage in septic shock, reperfusion injury and pulmonary inflammatory reaction [61]. NO can be toxic because gaseous $\mathrm{NO}$ reacts with $\mathrm{O}_{2}$ to create $\mathrm{NO}_{2}$, which can cause lung damage in levels proportional to the concentrations of oxygen and NO. When there are high concentrations of oxygen and $\mathrm{NO}$, large quantities of $\mathrm{NO}_{2}$ are produced; therefore, if the level of NO cannot be reduced it is necessary to reduce the level of oxygen to prevent toxicity. In general, more than $5 \mathrm{ppm}$ of $\mathrm{NO}_{2}$ can cause pulmonary toxicity [62]. In animals, $\mathrm{NO}_{2}$ has been reported to cause damage in Hulle cells, epileptic contractions and fibrostic lesions $[63,64]$. Additionally, although it is known that chronic exposure to NO can lead to respiratory tract hypersensitivity, bronchitis and cancer, there have not been many reports of pulmonary toxicity in response to short-term exposure [63].

As mentioned above, inhaled $\mathrm{NO}$ is rapidly absorbed into the blood stream, where it combines with the heme in $\mathrm{Hb}$ and oxides to create Met-Hb. This oxidated $\mathrm{Hb}$ has less ability to deliver oxygen. Accordingly, many clinical studies have been conducted to evaluate the effects of this increased met$\mathrm{Hb}$ concentration, but there have been no clinical reports of seriously reduced function of oxygen delivery. Rather, in patients administered high levels of $\mathrm{NO}$, an increase in met-Hb levels is generally observed, but these levels drop immediately after the $\mathrm{NO}$ level is reduced $[11,12,15,51,54,65]$.

Liquid $\mathrm{NO}$ reacts to oxygen much faster than gaseous $\mathrm{NO}$ to form the strong oxidant, $\mathrm{NO}_{3}{ }^{-}$, which can cause tissue damage via mediated oxidation [66-68]. As previously mentioned, when $\mathrm{NO}$ is used to treat adult respiratory failure and sepsis, it is important to realize that the cGMP-mediated vascular smooth muscle vasodilation and toxic radical production can actually worsen any inflammatory reaction, which can result in sepsis developing into septic shock.

The mechanism by which the effects of NO occur has not yet been fully elucidated; however, it is known to induce toxicity 
in platelets [69]. Additionally, it is dangerous to use NO in premature infants and child patients with intraventricular hemorrhage because NO has atrophic, nonproliferative properties that cause platelet inhibition [69]. When NO is used for the treatment of such cases, it is important to be mindful of $\mathrm{NO}_{2}{ }^{-}$production, the $\mathrm{NO}$ and oxygen levels, systemic inflammation and hemorrhagic tendencies. Specifically, the level of $\mathrm{NO}_{2}{ }^{-}$must be kept below 5 ppm. Additionally, the level of oxygen must be kept low while maintaining a high flow rate. Furthermore, the soda lime filter must be checked, the surrounding air must not be polluted by $\mathrm{NO}_{2}{ }^{-}$and the patient's $\mathrm{NO}_{2}{ }^{-}$level and met-Hb level must be monitored continuously.

\section{Other therapeutic modalities for pulmonary hypertension}

\section{O-nitrosoethanol (ENO)}

A portion of $\mathrm{NO}$ is transformed into RSNO, which is resistant to oxidation and does not become inactive. As a result, RSNO can react continuously. ENO does not react with oxygen or NO; therefore, its presence leads to a notable increase in endogenous RSNO in the alveolus and the respiratory tract. Accordingly, ENO inhalation can immediately reduce hypoxic pulmonary vasoconstriction, and there is no increase in rebound pulmonary pressure or decrease in oxidation when weaning from ENO. Moreover, cardiac output is stabilized, reduced systemic blood pressure is infrequent and the ventilation/perfusion ratio imbalance is mitigated, therefore, ENO is effective for the treatment of PHT accompanied by hypoxemia or accompanied by right ventricular failure [70].

Pulsating ENO inhalation is reported effective at treating PHT and oxidation because this treatment maximizes the effect of sending gas in well-ventilated bronchopulmonary segments and helps NO be exhaled during the rebreathing ventilation cycle [71].

\section{Sildenafil}

Sildenafil is an oral Phosphodiesterase (PDEs)-5 inhibitor that is known to be a safe and effective substitute for NO [72-74]. PDE inhibitors prevent the destruction of intraceullar CGMP, which leads to heightened pulmonary vasodilation [74] (Fig. 4). The use of sildenafil alone or with $\mathrm{NO}$ increases the cardiac index, brings no change to the systemic blood pressure, and is effective when administered as a one-time oral medication. Other inhibitors such as tadalafil and vardenafil also act as pulmonary vasodilators, but do not increase the effects of oxidization [75]. Recent long-term studies have reported that there is a strong synergistic effect when tadalafil and vardenafil are administered together with iloprost [76].

\section{Bosentan}

The endothelin (ET) receptor-inhibitor, bosentan, also induces hemodynamic and functional improvements in PHT patients [77]. The effects of bosentan occur via the blockage of ET receptors and increased internal activity of endogenous NO. The effects of bosentan can be magnified when it is administered in combination with $\mathrm{NO}$ [78].

\section{Natriuretic peptides}

Similar to NO, atrial natriuretic peptides (ANP) and brain natriuretic peptides (BNP) elevate intracellular cGMP, which in turn controls the vessel tone and affects vascular relaxation. ANP is produced in the atrium whereas BPN is produced in the ventricle. Both ANP and BNP have half lives and can only elevate CGMP to a certain point. Indeed, if the BNP level rises above the necessary level, it signifies a bad prognosis [79]. However, during acute hypoxia, ANP and BNP production increases, which reduces pulmonary resistance and the pressure load in the right ventricle, thereby preventing right ventricular failure. Even during chronic hypoxia, the blood concentration of ANP and BNP is high. Extrinsic ANP also reduces acute hypoxic pulmonary vasoconstriction and rightventricular strain, while BNP shows similar effects [80].

BNP is used for diagnostic purposes when there are elevated plasma concentrations, left ventricular dysfunction, severe worsening of the right ventricular dysfunction and PHT accompanied by chronic pulmonary disorders [81-83]. Additionally, BNP is used to treat left ventricular dysfunction patients by reducing pulmonary resistance. In mitral disorders, BNP attenuates PHT. In addition, it has been reported that the administration of BNP with sildenafil reduces pulmonary resistance; however, more research on that topic is needed [84].

Overall, NO inhalation has been shown to effectively reduce pre- and post surgical PHT. Additionally, NO can be used during liver-transplants and ventilation therapy for chronic pulmonary disorder patients as well as in cardiac patients. However, NO inhalation is required a complex delivery device andaccurate toxicity-monitoring device. Additionally, $\mathrm{NO}_{2}{ }^{-}$and $\mathrm{NO}_{3}{ }^{-}$formed during treatment can have toxic sideeffects and the chronic administration of NO has another problem. To overcome these limitations, the use of sildenafil and other PDE inhibitors, as well as ANP and other orally/ intravenously administered drugs is being evaluated. Future studies should enable the development on new drugs and liquid forms of NO that can overcome the side-effects and systemic hemodynamics. 


\section{References}

1. Tilton RG, Brock TA, Dixon RA. Therapeutic potential of endothelin receptor antagonists and nitric oxide donors in pulmonary hypertension. Expert Opin Investig Drugs 2001; 10: 1291-308.

2. Weir EK AS, Rubin LJ. Pulmonary hypertension. In: Cardiovascular medicine. Edited by Willerson JT CJ: New York, Churchill Livingstone. 1995, pp 1493-523.

3. De Backer TLM, Smedema JP, Carlier SG. Current management of primary pulmonary hypertension. BioDrugs 2001; 15: 801-17.

4. Attisano L, Wrana JL. Signal transduction by the TGF-beta superfamily. Science 2002; 296: 1646-7.

5. Wessel DL, Adatia I, Giglia TM, Thompson JE, Kulik TJ. Use of inhaled nitric oxide and acetylcholine in the evaluation of pulmonary hypertension and endothelial function after cardiopulmonary bypass. Circulation 1993; 88: 2128-38.

6. Wessel DL, Adatia I. Clinical applications of inhaled nitric oxide in children with pulmonary hypertension. Adv Pharmacol 1995; 34: 475-504.

7. Napoli C, Loscalzo J. Nitric oxide and other novel therapies for pulmonary hypertension. J Cardiovasc Pharmacol Ther 2004; 9: 1-8.

8. Reeves JT HJ. Experimental models of pulmonary hypertension. In: Pulmonary hypertension. Edited by weir EK RJ: Mount Kisco, Futura. 1984, pp 361-91.

9. Hopkins N, McLoughlin P. The structural basis of pulmonary hypertension in chronic lung disease: remodelling, rarefaction or angiogenesis? J Anat 2002; 201: 335-48

10. LM R. Structural remodelling of the pulmonary vasculature by environmental change and disease. In: The pulmonary circulation and gas exchange. Edited by Wagner WW WE: Mount Kisco, Furura. 1994, pp 77-110.

11. Zapol WM, Rimar S, Gillis N, Marletta M, Bosken CH. Nitric oxide and the lung. Am J Respir Crit Care Med 1994; 149: 1375-80.

12. Zapol WM, Hurford WE. Inhaled nitric oxide in adult respiratory distress syndrome and other lung diseases. Adv Pharmacol 1994; 31: 513-30.

13. Zapol WM, Falke KJ, Hurford WE, Roberts JD Jr. Inhaling nitric oxide: a selective pulmonary vasodilator and bronchodilator. Chest 1994; 105: 87S-91S.

14. Hobbs AJ IL. The nitric oxide-cyclin GMP signal transduction system. In: Nitric oxide and the lung. Edited by Zapol WM, Bloch KD: New York, Dekker. 1997, pp 1-57.

15. Roberts JD Jr, Fineman JR, Morin FC 3rd, Shaul PW, Rimar S, Schreiber MD, et al. Inhaled nitric oxide and persistent pulmonary hypertension of the newborn. The Inhaled Nitric Oxide Study Group. N Engl J Med 1997; 336: 605-10.

16. Furchgott RF, Zawadzki JV. The obligatory role of endoth- elial cells in the relaxation of arterial smooth muscle by acetylcholine. Nature 1980; 288: 373-6.

17. Palmer RMJ, Ferrige AG, Moncada S. Nitric-oxide release accounts for the biological-activity of endothelium-derived relaxing factor. Nature 1987; 327: 524-6.

18. Barbera JA, Peinado VI, Santos S, Ramirez J, Roca J, Rodriguez-Roisin R. Reduced expression of endothelial nitric oxide synthase in pulmonary arteries of smokers. Am J Respir Crit Care Med 2001; 164: 709-13.

19. Trembath RC, Thomson JR, Machado RD, Morgan NV, Atkinson C, Winship I, et al. Clinical and molecular genetic features of pulmonary hypertension in patients with hereditary hemorrhagic telangiectasia. Adv Pharmacol 2001; 345: 325-34.

20. Brayden JE, Nelson MT. Regulation of arterial tone by activation of calcium-dependent potassium channels. Science 1992; 256: 532-5.

21. Fleming I, Bauersachs J, Busse R. Calcium-dependent and calcium-independent activation of the endothelial NO synthase. J Vasc Res 1997; 34: 165-74.

22. Archer S, Rich S. Primary pulmonary hypertension - A vascular biology and translational research "work in progress". Circulation 2000; 102: 2781-91.

23. Hampl V, Herget J. Role of nitric oxide in the pathogenesis of chronic pulmonary hypertension. Physiol Rev 2000; 80: 1337-72.

24. Robertson BE, Warren JB, Nye PCG. Inhibition of nitricoxide synthesis potentiates hypoxic vasoconstriction in isolated rat lungs. Exp Physiol 1990; 75: 255-7.

25. Barer G, Emery C, Stewart A, Bee D, Howard P. Endothelial control of the pulmonary circulation in normal and chronically hypoxic rats. J Physiol 1993; 463: 1-16.

26. Persson MG, Kalzen H, Gustafsson LE. Oxygen or low concentrations of nitric-oxide reverse pulmonary vasoconstriction induced by nitric-oxide synthesis inhibition in rabbits. Acta Physiol Scand 1994; 150: 405-11.

27. Blitzer ML, Loh E, Roddy MA, Stamler JS, Creager MA. Endothelium-derived nitric oxide regulates systemic and pulmonary vascular resistance during acute hypoxia in humans. J Am Coll Cardiol 1996; 28: 591-6.

28. Isaacson TC, Hampl V, Weir EK, Nelson DP, Archer SL. Increased endothelium-derived no in hypertensive pulmonary circulation of chronically hypoxic rats. J Appl Physiol 1994; 76: 933-40.

29. Fagan KA, Tyler RC, Sato K, Fouty BW, Morris KG, Huang $\mathrm{PL}$, et al. Relative contributions of endothelial, inducible, and neuronal NOS to tone in the murine pulmonary circulation. Am J Physiol 1999; 277: L472-8.

30. Fagan KA, Fouty BW, Tyler RC, Morris KG, Hepler LK, Sato $K$, et al. The pulmonary circulation of homozygous of heterozygous eNOS-null mice is hyperresponsive to mild hypoxia. J Clin Invest 1999; 103: 291-9. 
31. Frostell C, Fratacci MD, Wain JC, Jones R, Zapol WM. Inhaled nitric oxide. A selective pulmonary vasodilator reversing hypoxic pulmonary vasoconstriction. [erratum appears in Circulation 1991 Nov;84(5):2212]. Circulation 1991; 83: 2038-47.

32. Pepke-Zaba J, Higenbottam TW, Dinh-Xuan AT, Stone D, Wallwork J. Inhaled nitric oxide as a cause of selective pulmonary vasodilatation in pulmonary hypertension. Lancet 1991; 338: 1173-4.

33. Kinsella JP, Truog WE, Walsh WF, Goldberg RN, Bancalari E, Mayock DE, et al. Randomized, multicenter trial of inhaled nitric oxide and high-frequency oscillatory ventilation in severe, persistent pulmonary hypertension of the newborn. J Pediatr 1997; 131: 55-62.

34. Kinsella JP, Abman SH. Inhaled nitric oxide: current and future uses in neonates. Semin Perinatol 2000; 24: 387-95.

35. Kinsella JP, Abman SH. Inhaled nitric oxide and high frequency oscillatory ventilation in persistent pulmonary hypertension of the newborn. Eur J Pediatr 1998; 157 (Suppl 1): S28-30.

36. Clark RH, Kueser TJ, Walker MW, Southgate WM, Huckaby $J$, Perez JA, et al. Low-dose nitric oxide therapy for persistent pulmonary hypertension of the newborn. Clinical Inhaled Nitric Oxide Research Group. N Engl J Med 2000; 342: 469-74.

37. Cremona G, Xuan ATD, Higenbottam TW. Endotheliumderived relaxing factor and the pulmonary circulation. Lung 1991; 169: 185-202.

38. Davidson D, Barefield ES, Kattwinkel J, Dudell G, Damask $M$, Straube $R$, et al. Inhaled nitric oxide for the early treatment of persistent pulmonary hypertension of the term newborn: a randomized, double-masked, placebocontrolled, dose-response, multicenter study. The I-NO/ PPHN Study Group. Pediatrics 1998; 101: 325-34.

39. Day RW, Lynch JM, White KS, Ward RM. Acute response to inhaled nitric oxide in newborns with respiratory failure and pulmonary hypertension. Pediatrics 1996; 98: 698705.

40. Pietro DA, LaBresh KA, Shulman RM, Folland ED, Parisi $A F$, Sasahara AA. Sustained improvement in primary pulmonary hypertension during six years of treatment with sublingual isoproterenol. N Engl J Med 1984; 310: 1032-4.

41. Artman M, Parrish MD, Boerth RC, Boucek RJ Jr, Graham TP Jr. Short-term hemodynamic effects of hydralazine in infants with complete atrioventricular canal defects. Circulation 1984; 69: 949-54.

42. Argenziano M, Choudhri AF, Moazami N, Rose EA, Smith $C R$, Levin HR, et al. Randomized, double-blind trial of inhaled nitric oxide in LVAD recipients with pulmonary hypertension. Ann Thorac Surg 1998; 65: 340-5.

43. Fattouch K, Sbraga F, Bianco G, Speziale G, Gucciardo M,
Sampognaro R, et al. Inhaled prostacyclin, nitric oxide, and nitroprusside in pulmonary hypertension after mitral valve replacement. J Card Surg 2005; 20: 171-6.

44. Goldman AP, Delius RE, Deanfield JE, Macrae DJ. Nitric oxide is superior to prostacyclin for pulmonary hypertension after cardiac operations. Ann Thorac Surg 1995; 60: 300-5.

45. Radovancevic B, Vrtovec B, Thomas CD, Croitoru M, Myers TJ, Radovancevic R, et al. Nitric oxide versus prostaglandin E1 for reduction of pulmonary hypertension in heart transplant candidates. J Heart Lung Transplant 2005; 24: 690-5.

46. Schmid ER, Burki C, Engel MH, Schmidlin D, Tornic M, Seifert B. Inhaled nitric oxide versus intravenous vasodilators in severe pulmonary hypertension after cardiac surgery. Anesth Analg 1999; 89: 1108-15.

47. Solina A, Papp D, Ginsberg S, Krause T, Grubb W, Scholz P, et al. A comparison of inhaled nitric oxide and milrinone for the treatment of pulmonary hypertension in adult cardiac surgery patients. J Cardiothorac Vasc Anesth 2000; 14 : 12-7.

48. Vater Y, Martay K, Dembo G, Bowdle TA, Weinbroum AA. Intraoperative epoprostenol and nitric oxide for severe pulmonary hypertension during orthotopic liver transplantation: a case report and review of the literature. Med Sci Monit 2006; 12: CS115-8.

49. Flondor M, Merkel M, Hofstetter C, Irlbeck M, Frey L, Zwissler B. The effect of inhaled nitric oxide and inhaled iloprost on hypoxaemia in a patient with pulmonary hypertension after pulmonary thrombarterectomy. Anaesthesia 2006; 61: 1200-3.

50. Winterhalter M, Simon A, Fischer S, Rahe-Meyer N, Chamtzidou N, Hecker $\mathrm{H}$, et al. Comparison of inhaled iloprost and nitric oxide in patients with pulmonary hypertension during weaning from cardiopulmonary bypass in cardiac surgery: a prospective randomized trial. J Cardiothorac Vasc Anesth 2008; 22: 406-13.

51. Kovalchin JP, Mott AR, Rosen KL, Feltes TF. Nitric oxide for the evaluation and treatment of pulmonary hypertension in congenital heart disease. Tex Heart Inst J 1997; 24: 30816.

52. Beghetti M, Habre W, Friedli B, Berner M. Continuous low dose inhaled nitric oxide for treatment of severe pulmonary hypertension after cardiac surgery in paediatric patients. Br Heart J 1995; 73: 65-8.

53. Day RW, Lynch JM, Shaddy RE, Orsmond GS. Pulmonary vasodilatory effects of 12 and 60 parts per million inhaled nitric oxide in children with ventricular septal defect. Am J Cardiol 1995; 75: 196-8.

54. Roberts JD Jr, Lang P, Bigatello LM, Vlahakes GJ, Zapol WM. Inhaled nitric oxide in congenital heart disease. Circulation 1993; 87: 447-53.

55. Allman KG, Young JD, Carapiet D, Stevens JE, Ostman- 
Smith I, Archer LN. Effects of oxygen and nitric oxide in oxygen on pulmonary arterial pressures of children with congenital cardiac defects. Pediatr Cardiol 1996; 17: 24650.

56. Buga GM, Griscavage JM, Rogers NE, Ignarro LJ. Negative feedback regulation of endothelial cell function by nitric oxide. Circ Res 1993; 73: 808-12.

57. Gerlach H, Rossaint R, Pappert D, Falke KJ. Time-course and dose-response of nitric-oxide inhalation for systemic oxygenation and pulmonary-hypertension in patients with adult-respiratory-distress-syndrome. Eur J Clin Invest 1993; 23: 499-502.

58. Adatia I, Atz AM, Jonas RA, Wessel DL. Diagnostic use of inhaled nitric oxide after neonatal cardiac operations. J Thorac Cardiovasc Surg 1996; 112: 1403-5.

59. Houde C, Bohn DJ, Freedom RM, Rabinovitch M. Profile of pediatric-patients with pulmonary-hypertension judged by responsiveness to vasodilators. Br Heart J 1993; 70: 4618.

60. Rassaf T, Preik M, Kleinbongard P, Lauer T, Heiss C, Strauer $\mathrm{BE}$, et al. Evidence for in vivo transport of bioactive nitric oxide in human plasma. J Clin Invest 2002; 109: 1241-8.

61. Kooy NW, Royall JA, Ye YZ, Kelly DR, Beckman JS. Evidence for in-vivo peroxynitrite production in human acute lung injury. Am J Respir Crit Care Med 1995; 151: 1250-4.

62. Foubert L, Fleming B, Latimer R, Jonas M, Oduro A, Borland $C$, et al. Safety guidelines for use of nitric-oxide. Lancet 1992; 339: 1615-6.

63. Gaston B, Drazen JM, Loscalzo J, Stamler JS. The biology of nitrogen-oxides in the airways. Am J Respir Crit Care Med 1994; 149: 538-51.

64. Massaro AF, Gaston B, Kita D, Fanta C, Stamler JS, Drazen $J M$. Expired nitric-oxide levels during treatment of acute asthma. Am J Respir Crit Care Med 1995; 152: 800-3.

65. Askew GL, Finelli L, Genese CA, Sorhage FE, Sosin DM, Spitalny KC. BOILERBAISSE - An outbreak of methemoglobinemia in new-jersey in 1992. Pediatrics 1994; 94: 381-4.

66. Bevilacqua MP, Nelson RM. Selectins. J Clin Inves 1993; 91: 379-87.

67. Linden DJ, Dawson TM, Dawson VL. An evaluation of the nitric oxide/cgmp/cgmp-dependent protein-kinase cascade in the induction of cerebellar long-term depression in culture. J Neurosci 1995; 15: 5098-105.

68. Springer TA. Adhesion receptors of the immune-system. Nature 1990; 346: 425-34.

69. Stamler JS, Osborne JA, Jaraki O, Rabbani LE, Mullins M, Singel $D$, et al. Adverse vascular effects of homocysteine are modulated by endothelium-derived relaxing factor and related oxides of nitrogen. J Clin Invest 1993; 91: 30818.

70. Moya MP, Gow AJ, Califf RM, Goldberg RN, Stamler JS. Inhaled ethyl nitrite gas for persistent pulmonary hypertension of the newborn. Lancet 2002; 360: 141-3.

71. Heinonen $E$, Merilainen P, Hogman M. Administration of nitric oxide into open lung regions: delivery and monitoring. Br J Anaesth 2003; 90: 338-42.

72. Michelakis EA. The role of the NO axis and its therapeutic implications in pulmonary arterial hypertension. Heart Fail Rev 2003; 8: 5-21.

73. Raja SG, Danton MD, MacArthur KJ, Pollock JC. Treatment of pulmonary arterial hypertension with sildenafil: From pathophysiology to clinical evidence. J Cardiothorac Vasc Anesth 2006; 20: 722-35.

74. Steiner MK, Preston IR, Klinger JR, Hill NS. Pulmonary hypertension: inhaled nitric oxide, sildenafil and natriuretic peptides. Curr Opin Pharmacol 2005; 5: 245-50

75. Ghofrani HA, Voswinckel R, Reichenberger F, Olschewski $H$, Haredza P, Karadas B, et al. Differences in hemodynamic and oxygenation responses to three different phosphodiesterase- 5 inhibitors in patients with pulmonary arterial hypertension - A randomized prospective study. J Am Coll Cardiol 2004; 44: 1488-96.

76. Simonneau G, Rubin L, Galie N, Barst RJ, Fleming TR, Frost $A E$, et al. Addition of Sildenafil to Long-Term Intravenous Epoprostenol Therapy in Patients with Pulmonary Arterial Hypertension A Randomized Trial. Ann Intern Med 2008; 149: 521-102.

77. Rubin LJ, Badesch DB. Evaluation and management of the patient with pulmonary arterial hypertension. Ann Intern Med 2005; 143: 282-92.

78. Ignarro LJ, Napoli C, Loscalzo J. Nitric oxide donors and cardiovascular agents modulating the bioactivity of nitric oxide - An overview. Circ Res 2002; 90: 21-8.

79. Tsutamoto T, Wada A, Maeda K, Hisanaga T, Maeda Y, Fukai $D$, et al. Attenuation of compensation of endogenous cardiac natriuretic peptide system in chronic heart failurePrognostic role of plasma brain natriuretic peptide concentration in patients with chronic symptomatic left ventricular dysfunction. Circulation 1997; 96: 509-16.

80. Adnot S, Chabrier PE, Brunbuisson C, Viossat I, Braquet P. Atrial natriuretic factor attenuates the pulmonary pressorresponse to hypoxia. J Appl Physiol 1988; 65: 1975-83.

81. Klinger JR, Warburton RR, Pietras L, Hill NS. Brain natriuretic peptide inhibits hypoxic pulmonary hypertension in rats. $J$ Appl Physiol 1998; 84: 1646-52.

82. Leuchte HH, Holzapfel M, Baumgartner RA, Ding I, Neurohr 
C, Vogeser M, et al. Clinical significance of brain natriuretic peptide in primary pulmonary hypertension. J Am Coll Cardiol 2004; 43: 764-70.

83. Leuchte HH, Neurohr C, Baumgartner R, Holzapfel M, Giehrl W, Vogeser $M$, et al. Brain natriuretic peptide and exercise capacity in lung fibrosis and pulmonary hyper- tension. Am J Respir Crit Care Med 2004; 170: 360-5.

84. Preston IR, Hill NS, Gambardella LS, Warburton RR, Klinger JR. Synergistic effects of ANP and sildenafil on CGMP levels and amelioration of acute hypoxic pulmonary hypertension. Exp Biol Med (Maywood) 2004; 229: 920-5. 